TITLE:

\title{
Generation of retinal cells from mouse and human induced pluripotent stem cells(Abstract_要 旨)
}

$\operatorname{AUTHOR}(\mathrm{S}):$

Hirami, Yasuhiko

\section{CITATION:}

Hirami, Yasuhiko. Generation of retinal cells from mouse and human induced pluripotent stem cells. 京都大学, 2010, 博士 (医学)

ISSUE DATE:

2010-01-25

URL:

http://hdl.handle.net/2433/97948

RIGHT: 


\begin{tabular}{|l|l|c|l|}
\hline 京都大学 & 博士 (医学) & 氏 名 & 平見 恭彦 \\
\hline 論文題目 & $\begin{array}{l}\text { Generation of retinal cells from mouse and human induced pluripotent } \\
\text { stem cells (マウスおよびヒト人工多能性幹細胞由来網膜細胞の作製) }\end{array}$ \\
\hline
\end{tabular}

\section{(論文内容の要旨)}

網膜色素変性は遺伝子の異常による網莫視細胞の細胞死が進行性の網幙変性を引き起こす遺伝的網莫 変性疾患である。変性が進行した網膜に対しては現在有効な機能回復の手段はなく、視細胞移植による 視機能再生が有望な治療法の一つである。これまで本疾患の患者への胎児網膜細胞の移植の報告がある がいまだ治療法として確立されておらず治療の可能性を示唆するにとどまっている。また動物実験レ心゙ ルでは疾患モデル網膜に対する胎坚あるいは新生児の幼若な網膜、体性幹細胞あるいは胚性幹(ES)細胞 から分化誘導された視細胞の移植効果が報告されている。細胞移植を臨床の治療に応用するにあたって は移植する細胞を大量に準備する必要があり、ES 細胞のように自己複製能、分化多能性を有する細胞 は移植細胞源として有望であるが、同種間移植による移植後の拒絶反応の問題も解決する必要がある。

一方 2006 年に体細胞へのレトロウィルスによる遺伝子導入により $\mathrm{ES}$ 細胞と同様に自己複製能、分 化多能性を持つ人工多能性幹(induced pluripotent stem; iPS)細胞が発表され、臨床応用の面で患者本人 から採取した細胞を大量に培養して必要な組織や細胞へ分化させることができる可能性が示された。こ れまで、ES 細胞からの網膜細胞への誘導については網膜色素上皮、網鄚視細胞の分化誘導が報告され ており、ES 細胞が網膜再生医療において移植細胞の供給源となりうる可能性が示されている。本研究 では ES 細胞から網膜細胞を分化誘導寸る方法をiPS 細胞一応用し同様に網膜細胞への分化誘導が可能 かどうか検討した

マウス iPS 細胞からの分化誘導は、未分化iPS 細胞をフィーダ一細胞と分離して無血清培地中で孚遊 部養を 9 日間行い、その間、培地にWnt およびNodal シグナルの阻害薬を加えた。その後接着培養を 行い, 約 15 日目に神経網膜の前駆細胞のマーカーである Rx と Pax6 陽性の細胞およひ網膜色素上皮の 前駆細胞のマーカーである Mitf と Pax6 陽性の細胞を免疫細胞染色およびRT-PCR で確認した。さら に分化開始後約 30 日目にタイトジャンクションのマーカーであるZO-1て染色される多角形状の細胞を 確認し、約 45 日目には網膜色素上皮のマーカーである RPE65 陽性の細胞を確認した。分化開始 30 日 目には視細胞の前駆細胞のマーカーである Crx 陽性の細胞も確認し、その後から培地にレチノイン酸お よびタウリンを添加することにより、視細胞のマーカーであるリカバリンとロドプシン陽性の細胞を確 認した。同様にヒト iPS 細胞からの分化誘導は、未分化iPS 細胞をフィーダ一細胞と分離して無血清培 地中で浮遊培養を 20 日間行い、その間、培地にWnt およびNodal シグナルの阻害薬を加えた。その後 接着培養を行い、約 40 日目に神経網膜の前駆細胞のマーカーである Rx と Pax6 陽性の細胞およひ網膜 色素上皮の前駆細胞のマーカーであるMitf と Pax6 陽性の細胞を確認した。さらに分化開始後約 60 日 目に色素を有寸る多角形の網莫色素上皮椂の細胞を確認した。分化開始 30 日目には視細胞の前駆細胞 のマーカーである Crx 陽性の細胞も確認し、その後から培地にレチノイン酸およびタウリンを添加する ことにより、視細胞のマーカーであるリカバリンとロドプシン陽性の細胞を確認した。以上の結果から、 ES 細胞からの分化誘導と同様の方法を用いてほぼ同等の効率でマウスおよびヒト iPS 細胞からも網膜 視細胞および色素上皮細胞の分化誘導が可能であったと考えられた。今後、網膜変性モデル動物への移 植実験などにより、分化誘導された網募細胞の機能解析、免疫拒絶反応の検討なじが必要と考えられる が、網膜細胞移植の細胞源としてiPS 細胞を利用できる可能性が示された。
（論文審査の結果の要旨）

網膜色素変性などの網膜変性疾患に対し、細胞移植は機能回復への一つの手段と考えられ、細胞移植 治療の開発に際して患者自身から細胞が安全かつ十分に得ることができれば移植細胞の供給源として理 想的である。本研究では寸でにマウスおよびヒトES細胞から網膜色素上皮細胞およひ視細胞への分化誘 導で確立した方法を適用してマウスおよびヒトiPS細胞から分化誘導を行った。未分化マウスおよびヒ卜 iPS細胞を無血清培地中で浮遊細胞塊を形成させ培養した後、接着培養を行い網膜前駆細胞のマーカー (Rx、Pax6)およひ視細胞のマーカー(ロドプシン、リカバリン)の発現を免疫細胞染色で検討したところ、 WntおよびNodalシグナルの阻害薬の存在下に浮遊細胞塊を形成させ培養した後、接着培養を行うと網 膜前駆細胞のマーカーであるRx/Pax6陽性の細胞が一部に認められ、ヒトiPS細胞では色素を有寸る多角 形の網莫色素上皮様の細胞が出現した。その後、培地に視細胞への分化誘導因子であるレチノイン酸と タウリンを加え、さらに接着培養を続けた結果、網膜視細胞のマーカーであるリカバリンとロドプジン の発現を認めた。マウスおよびヒトES細胞から網鄚細胞への分化誘導法を用いてマウスおよびヒトPPS 細胞においても網膜色素上皮細胞および視細胞のマーカーを発現する細胞の出現を認め、iPS細胞が網膜 疾患への細胞移植治療の細胞供給源となる可能性が示唆された。

以上の研究はiPS細胞由来の網暯細胞の分化誘導方法の解明に貢献し網膜变性疾患に対寸る細胞移植 治療の開発に寄与寸るところが多い

したがって、本論文は博士(医学)の学位論文として価値あるものと認める。

なお、本学位授与申請者は、平成21年12月8日実施の論文内容とそれに関連した試問を受け、合格と 認められたものである。 